\title{
TANBUR AS STRINGED MUSIC INSTRUMENT: ROLE, QUALITIES, INFLUENCES ON YARSANISM
}

\author{
Seyedeh Sara Seyedahmady Zavieh ${ }^{1}$, Mohammad-Reza Darvishi ${ }^{2}$ and Azadeh \\ Mehrpouyan $^{3 *}$ \\ ${ }^{1}$ Mrs., Department of Composition, Faculty of Music, Tehran University of Art, Tehran, Iran, \\ Sarah.zavieh@yahoo.com \\ ${ }^{2}$ Mr., Department of Composition, Faculty of Fine Art, University of Tehran, Tehran, \\ Iran,aftab.aftabd@yahoo.com \\ ${ }^{3}$ Asst. Prof. Dr., Department of English Literature, Central Tehran Branch, Islamic Azad University, \\ Tehran, Iran, dr.mehrpooyan@gmail.com \\ ${ }^{*}$ Corresponding author
}

\begin{abstract}
This research extends on historical background and mythic structure of Yarasanism through a survey of principal concepts of their beliefs. History of Tanbur and its usages are investigated through introducing three major Mughams with a special focus on Haqqni Mugham. This research study was conducted via descriptive -analytical method and library method. This study also identifies some features and symbols of Tanbour as music instrument and its correlation with Yarsan beliefs including individuals, numbers, legends, etc. This research also addresses a relation between Tanbour and Yarsan identity. The results show that Tanbour preserved language, literature (poetry), and music.
\end{abstract}

Keywords: Tanbour, Yarasan Music, Yarsanism, Mysticism, Poetry

\section{INTRODUCTION}

\subsection{Yarsanism and Origin: History, Place, Ideology}

The word "Yarsanism" in Persian is a compound word (Ahl-e-Haqq) that including its general meaning of fan or desirous, and supporter of truth, specifically refers the followers of a particular mystical religion. The main issue on followers' thoughts of Yarsanism is a certain kind of mental and physical improvement of man through self-purification, spiritual meditation and physical devotion (Ardalan, 2007). According to some scattered documents, the history of Ahl-e-Haqq began from the second, fourth or sixth century specifically, while according to narratives it may date back to Seventh or eighth century and the advent of "Sultan Isaac" (Sahak). (Ardalan, 2007)

Sultan Sahak himself had also some disciples who have been divided into the following groups: "Haft- 
Tan","Haftvaneh", seven people from "Ghoul-Taas", "Haft-Haftvan", "Chehel-Tan", "Chehel- Cheheltanan", "Seventy two Murshids", "Seventy Two Murshids of Shahou"," Sixty six golden belt Slaves", "One Thousands and one eunuch Slaves", "Bivaar Thousand Slaves", and "Bivan Slaves". (Elahi, 1994) Studies that have been done by the orientalists seems that Yarsanism was initially a mixture of ancient Iranian beliefs and especially Zoroastrianism along with some thoughts of Manichean beliefs and Hinduism (reincarnation and transmigration), Christianity, Judaism, with a glaze of Sunni and Shia beliefs that spread and maintained by masters and Sufism in each era (Khodabandeh, 2003). Through the interpretation of intellectual opinions of Ahl-e-Haqq, various signs of the faith of Zoroaster, Mani, Mazdak, Jesus, Moses, Buddha, Mithraism and Iranian and non-Iranian sects can be found (Ardalan, 2007). Yarsanism rooted in history, geography and culture of the Aryan people; footprint of many of the beliefs and customs, stories, legends and myths of Iranian are clearly visible on it. These legends and histories that are mostly presented in oral literature are often ancient; when interpreted and philosophical lessons derived from the myths of them, these stories get a modern sense. The majority of the population of Ahl-e-Haqq is Kurds and minority of them is Lor and Turk. According to the documents, the Lorestan province was the origin place of the Ahl-e-Haqq sect (in a form rather than the same image of this sect that we know today). Based on the beliefs of Ahl-e Haqq, king Mubarak titled as "Shah Khushin" that was a manifestation of God and was born from a virgin mother named "Mama-Jalalah" appeared among the Lor tribes in the late third century and early fourth century AH and spread the method of truth among part of Lorestan people (Mokri, 1977). The main center of this sect till the seventh century of Islamic calendar was in the mentioned province; Afterwards spread to western parts of Kurdistan, and since the advent of "Sultan Sahak" has expanded to Kurdish areas of Iraq. Todays, the western regions of Iran and particularly Kermanshah and slopes of the Zagros are their major deployment centers (Ardalan, 2007).

Although the race of Ahl-e-Haqq known to be mostly original, but due to the multiplicity of Kurd tribes and their close relations with each other, there is possibility of changes in the race of Goran tribes as the main tribe of Ahl-e-Haqq. The language of Ahl-e-Haqq is mainly Gorani; this language is one of the dialects of Kurdish and northwestern branch of ancient Iran's language. (Ardalan, 2007)

\section{BACKGROUND OF AHL-E-HAQQ}

Ahl-e-Haqq is a sect with religious and ritual thoughts which have multiple semantic forms and the essence of their thinking is return to oneness. Holy books of Ahl-e-Haqq is called "Daftar" or "Kalaam". Daftars and Kalaams contains instructions and worldly Sharia, style and way of life, life and death of man, truth of life, remembrances, ideas and collective wisdom. The people Ahl-e-Haqq in their opinions retained ancient signs and meanings while utilizing adaptation of mythical culture with historical events. The arrangement of Ahl-eHaqq to preserve their history and heritage is resist and a constant struggle (Mokri, 1966). In this regard, dignitaries with real birth, life and death emerged in thinking and wisdom system of Ahl-e-Haqq as religious leaders who have deep relation with gnostic and mystical religions. Knowledge of Ahl-e-Haqq from the myths of various tribes due to the establishment of the Kurdish regions between the land of the Persians, Turks, Arabs, Azeris, Armenians and Georgians and cultural and geographical proximity with areas of Iranian civilization, Anatolia, Arabic and Jewish, Christian, Islamic and ancient Iranian religions enables them to cultivate spiritual and contemplative ritual religion. Interrelationship of ritual concepts and narratives rich of inexistence, creation, man birth and apocalyptical concepts is that much which in the present era a few (even among Ahl-e-Haqq) can achieve a proper understanding of these mysterious and semantic cues. For example: God or Creator of the universe in Yarsanism has also a human form and God's traits, actions, speech and manners narrated in details. This principle is the most important manifestation of beliefs in Yarsanism which called "Mazhariat". "Mazhar" In terms of Ahl-e-Haqq means a spirit that polished in the path of perfection and reflects the divine light (Elahi, 1994). To maintain a balance between real and mythological aspects of Ahl-e-Haqq, it is necessary to achieve a simultaneous perception of historical trends and comparative process of myths, culture and traditions of the Kurdish Ahl-e-Haqq; because they were forced to maintain their roots though permanent struggle and meanwhile keep necessary exchanges with the central government whenever needed. (Ardalan, 2007)

Ahl-e-Hagh believe that they are the very first creatures that God or the Creator of world created for dialogue and spiritual- physical life from himself. In Yarsan texts, the evolution of creatures and world has a mythological structure. The purpose of the creation is to place man at its center and origin of the creation i.e. God created himself in single man form (Ardalan, 2007). Also, Ahl-e-Haqq in their basic beliefs and holy names refer to four sacred concepts of honesty, purity, inexistence (perishing selfishness) and "Radaa" (service and sacrifice). These four words can define man while living. Origin and destination of man is related to these concepts and these are interdependent. 


\section{GENERAL CONCEPTS OF AHL-E-HAQQ BELIEFS}

\subsection{Dualism}

Ahl-e-Haqq know wisdom as good and warn about evil that stated as incomplete intellect. The principle of the supremacy of good over evil has been taken from Zoroastrian's thinking. Ahl-e-Haqq believe that man have two powers of thought and wisdom; an integral wisdom and an incomplete wisdom. Ahl-e-Haqq also believe that, every particle of the divine essence is always in circulation around the righteous and pure people. (Soori, 1965). Zoroastrianism emphasis on the dual forces of the universe. Although, the forces of good and light will eventually be universal, but its realization is subject to the destruction of evil and the Ahriman.

\subsection{Reincarnation}

Reincarnations means convert from don to don (garment to garment). Yarsanism alter the meaning of life and death through reincarnation. In the tortuous mystical sense, Man can accept other people garments and don them at different times while having the talent to reincarnate into animals, plants and inanimate entities as well. This means that only the body changes and spirit will be preserved. In Yarsanism, reincarnation in this sense that the spirit transfer from a body to another body purposeless, is totally negated and basically rejected. But another concept called becoming "Don to Don" is an inseparable truth from the ideology of Yarsanism. This concept states that every spirit should pass a cycle in a period of fifty thousand years to evolve. Ahl-e-Haqq knows the fourth verse of "Meraaj" Surah as the reason for their claim.

\subsection{Naming and Devotion}

Children of Ahl-e-Haqq must be present at the devotion ceremony after a week of their birth to become Ahle-Haqq. Father or his advocate takes his infant to "Jam-khaneh" to devote. Ceremony has several components; Among those: attending "Jam-khaneh", baby tasting nutmeg sacred fruit, bringing a piece of white linen, performing prayers and good wishes for the newborn are the most important. This ceremony is very similar to the child naming ceremony of Zoroastrian.

\section{ROLE OF TANBOUR}

This instrument that took different names and forms during the historical and cultural journey of Tanbour across different regions has mystical and epic character. Tanbour has a pear-shaped body and a long neck that thirteen frets tied on it. Headstock is connected to the neck of the instrument and in fact, headstock is actually the continuation of neck that on each of the front and surfaces of it, two tuning keys are placed which strings wrapped around them. Tanbour has four strings that usually tuned to different intervals. This instrument played with finger without a plectrum.

\subsection{Status of Tanbour in Ahl-e-Haqq Sufism}

Music and mysticism has always had a deep bond with each other and in most of the rituals and mystical sects, signs of the deep connection between the two can be found. Yasna reading or reciting litanies and prayers in Zoroastrian, cosmic instrumentals in the traditions of India and China, the Psalms reading of Jews, Quran reciting, Gregorian hymns in Christianity, sacred music of Ahl-e-Haqq, etc. are all pointing this bond. It is written in the "Saranjaam" texts of Ahl-e-Haqq that when spirit refused to mix with man body, with the order of God, Benjamin master blew the spirit into the body of man though playing Tanbour in Mugham "Tarz". Ahle-Haqq consider Tanbour as the symbol of God words and its respect is that much to be called Neda-al-haqq (voice of God) among them (During, 1989).

Through studying motifs and signs left by ancient tribes of Iran (Elam, Media and Assyria), it can be said that history of Tanbour is dating back to three to four thousand years BC. Stone sculptures in museums and remained ancient monuments in the Nebi Yunus hills in Mosul shows the history of this instrument around 1500 to 2000 B.C. Al Farabi, Aviccena, Abd-al-Qadir Maraghi, and Safi-al-Din Armavi comprehensively described Tanbour, different types of it, and its various intervals and tunings. Also, great Persian poets such as Ferdowsi, Rumi, Manouchehri, Nizami Ganjavi, Hafez and Abdul-Qadir Bidel repeatedly mentioned Tanbour in their works.

This instrument that has always reflect the spirituality of Ahl-e-Haqq is holy and divine among them, as it is quoted that Shah Khushin (late third century $\mathrm{AH}$ ) promised his reappearance in Hawraman and in a time that out-of-tune Tanbour of companions tuned again; and years after the death of Shah Khushin, his companions was passing a saddle near home of a master named Babanus that their Tanbour tuned and the companions realized that their Murshid is nearby (Moradi Quoted by Kaki, 2009). 
About Tanbour of Ahl-e-Haqq, Doring (1999) asserted that "Before the fourth century, still there wasn't a sacred instrument and this kind of allocation emerged in the fourth century $\mathrm{AH}$. When Shah Khushin, one of the greatest "Mazhar-Allah"s (manifestation of God), prior to the Sultan Sahak used Tanbour to accompany the fellowships, from that moment onwards, Tanbour became the holy instrument of Ahl-e-Haqq.

Great saints of this sect have played this instrument and passed a series of Dhikrs and compositions and added to it so that it can remain till today. Choosing this instrument for sacred music is a sign of unity and continuity between the mystical traditions of Central Asia... (Doring, 1999)

Darvishi (1991) in "Seven Ourang" which is a report of the first gathering of mystical musicians, stated about Tanbour music: "This particular type of music that can be heard only in the residential areas of Ahl-e-Haqq in Kermanshah is different from the other types of music in Kermanshah region; it can be guessed that Tanbour music dated back to centuries before the advent of Islam." Weight, types of intervals and melodic flow in this music aspect is completely ancient. Darvishi (1991) believes that studying this kind of music can help to clarify many of the issues and characteristics of the current "Radif" of traditional Iranian music. This instrument which is considered as ancient instrument of Iranians and ritual instrument of Ahl-e-Haqq is the only instrument allowed in Dhikr ceremonies of Yarsan cult (Ahl-e-Haqq) and it seems since the beginning of this cult, it is one of necessities of their gatherings.

\subsection{Applications of Tanbour}

Tanbour music due to its holiness and spiritual state does not play in every gathering and ceremony. Todays, this instrument cannot be used at weddings and similar events at any cost. In the celebrations, sometimes a few of ceremonial and virtual Mughams have been played in certain circumstances late night when the guests have gone and just some of the elders of the family remained. But, in other ceremonies of Yarsan it has been used including: in "Jam" ceremony and in "Jam-khaneh", or in holy places and shrines of Yarsan as well as mourning ceremonies.

\subsubsection{Performing Tanbour in the shrines}

Here shrine means shrines of Ahl-e-Haqq which are burial place of Murshids, masters and their elders; such as the shrine of "Sultan Sahak" in Uraman and shrine of "Baba Yadgar" in the mountains Dalahu, etc.

\subsubsection{Tanbour in Funeral Ceremonies}

Tanbour presence at the funeral is just to sing hymns to God for forgiveness of the deceased. Performing some Mughams of Tanbour is not to express or maximize grief in mourning but has religious aspect; and this means that it escorted the spirit which has flown from the body with pleasant tones so spirit has a pleasant journey toward God and to the source. Singers and performers of Tanbour in the ceremony that will be held at the third, seventh and fortieth days after death of deceased; after singing some Mughams by singing the "Hu Avval, Akhar Yaar" meaning "we have been with God and we will return" ceremony finish.

It's worth mentioning that, Ahl-e-Haqq people due to their own faith do not have any mourning and grief ceremonies for their dignitaries and masters.

\subsubsection{Using Tanbour in "Jam-khaneh"}

"Jam" means gather and a gathering place that Yarsan rituals are performed in a special ceremony. Tanbour plays an essential role in this ceremony; and duration of this ceremony vary from twenty minutes to two hours and maybe more. In this ceremony that has its own specific rituals, divine vows and prayers performed with a special ceremony that Tanbour has a significant role in it; and the purpose of performing this ceremony is only Dhikr and pray (Minorsky, 1921). In this ceremony first, "Pishravi-Pardivari" Mugham singed and played by Kalaam Singer for four to five minute. After that, one of the vocal Mughams performed that can be one of the ceremonial (Majlisi) or Kalaam Mughams. In this section, presented people in Jam circle affected and Jam atmosphere will convert into a spiritual atmosphere. This section continues for 5 to 15 minutes of vocal and instrumental depending on skills of musician and singer. After that, one of the Mughams which have heavy rhythms and certainly is one of the Kalaam Mughams will be performed; in this part, participants may have some problems in following and understanding the rhythm. But, because it is along with clapping and have specified verse that participants are familiar to and also Sar-Kalaam guide them like an orchestra conductor, usually there is no problem. Afterwards, several Mughams perform with faster rhythm that duration of this performance is depend on participants' mood. In this part of program, the passion of vocals and participants' enthusiasm is so high that sound of Tanbour heard roughly. In this part, Haqqani or Kalaam Mughams that have fast two beat and three beat rhythms will be used and just like third part, it is along with clapping. In this part of program, participants become very excited and all of them are 
intoxicated and have passion and special mood. Some of them start to Sama and lose themselves and do not accompany in repeating verses anymore; and just repeat some words like, Haqq, Hu and Ali. Some other participants respond verses with their special mood. Finally, "Pishravi-Pardivari" Mugham will be performed again that signals end of Dhikr and takes four to five minutes. And in this way, Dhikr ends and vows and needs prayed by Sayed and participants with saying "Hu Aval Akhar Yaar" prostrate and the ceremony ends (Kaki, 2009).

The importance of this research is to find alternative view of music as a vital tool serving culture and history and also determine the role that music can play in continuity and promote a mystical religion and language of a sect. this study can be a model for such this researches not only in music but also studies related to other fine arts; so maybe with gathering the heritage that our ancestors have left behind, can get closer to the old elements of a culture through fine art.

The principal objective of present study is to investigate the relationship between the Kalaams concepts with the trend of music and musical elements used in it. (Interpretation of mysticism in music) This study also aims to examine the role of Tanbour in the generation to generation transmission of Yarsanism religion to the followers of this cut as well as determining the role of Tanbour in preserving the language and ancient literature of Yarsanism.

This study hypothesizes Tanbour and its music had a decisive role in maintaining Yarsanism heritage in the areas of mysticism, language and literature. Spite of studying musical structure of Haqqani's Kalaams, somehow might achieve a greater understanding of the hidden meaning of the Kalaams.

This study was conducted through library analysis, interview and descriptive analysis.

This paper is organized as follows: mystical school of Yarsanism and Tanbour sacred instrument are introduced, next the musical structure of three Haqqani Mughams out of seventy-two Mughams and interpretation of the meaning and contents of these three Kalaams in clarifying their music are examined and afterwards, the unbreakable bond of language, music and mysticism in this sect are discussed.

\section{MATERIALS AND METHODS}

Mugham in Tanbour represents a sound basis, specific intervals between sounds, and particular roles that some of the sounds are responsible for in the melodic structure of Mugham. Most of the Tanbour's Mughams have a general pattern that provides a model for improvisation and creating songs. In general, Yarsan Mughams are seventy two Mughams. Although, these seventy two Mughams only includes Kalaam and ceremonial Mughams and does not include virtual Mughams; because, virtual Mughams are considered as Mughams of Horn instrument, does not placed in this classification.

\subsection{Mughams of Tanbour}

\subsubsection{Virtual Mughams}

Tasnifs, songs, joyful music, and many different samples of Kurdish music are placed in this section. These Mughams are newer than the other two Mughams (ceremonial and Kalaam). Although, these Mughams have less spirituality compared to the other Mughams but, have sublime artistic features. Originally these Mughams belong to Horn instrument.

\subsubsection{Ceremonial Mughams (Ancient)}

Ceremonial Mughams of Tanbour are a significant part of Tanbour Mughams which are ancient vocals of Kurd people, and in fact are Houreh Vocals (It is a continuous singing that vocalist sings countless lyrics sequentially. This vocal is the simplest, most basic and most noble form of music that dates back to the era of Zoroaster and is still common among the Western tribes of Iran). Existing narratives and specific flow of melody in these Mughams give them personality and an epic, mystical, romantic and sometimes earthy state. Ceremonial Mughams are language to express sorrow and happiness, separation and epics of an ancient music-lover nation that heal their inner wounds with them. (Moradi, Ali-Akbar, in Album cover of "Sur" ceremonial Mughams cassette). Ceremonial Mughams of Tanbour has lesser sanctity compared to Kalaam Mughams and these Mughams can be performed in mystic ceremonies and also in front of audiences.

\subsubsection{Haqqani Mughams (Kalaam, Yaari)}

Kalaam Mughams considered as the major and most important Mughams of Tanbour and have spiritual state and holiness. From the historical point of view dating back to the tenth to fourteenth centuries $\mathrm{AH}$ and first Mugham of Kalaam named "Shah Khushini" composed in tenth century AH in Persian language. This 
Mugham performed by "kalaam-Khaan" with Tanbour and vocal, and verses of these Mughams are sacred texts of Yarsanism which performed in Kurdish language and Hawrami dialect (same ancient accent of Goran people). These Mughams considered very sacred by Yarsan and usually performed only in Jam rituals for devoted people of Ahl-e-Haqq in Dhikr gatherings. Performing Kalaam Mughams outside of these gatherings except in rare cases has religious prohibition. According to beliefs of Ahl-e-Haqq, performing Kalaam for people who are not belong to this hierarchy and are not devotee is forbidden. In Kalaam Mughams sometimes music is superior to Kalaam while sometimes text has supremacy to music. In some others, both have equal importance. Number of Haqqani Mughams is known to be seventy two that in fact, it includes seventy two Sarband or Refrain that singed in Dhikr gathering and participants repeat it. Refrains are sometimes musically similar but their lyrics vary (Darvishi, 2001). In this paper, three Haqqani Mughams of "AAli-Gorzeh-Vish", "Haqq Haqq-Hu Hu-Ey-Aghay-e-Jafam", and "Rezhyan-Dalahu" are studied out of seventy two.

\section{RESULTS AND DISCUSSION}

Tanbour is decrees or secret-box of Haqqni Mughams and Mugham is fixed container of concepts that has constant basis and is unchangeable; therefore, Mugham and Tanbour has a relation similar to spirit and body in this religion. Spirit is like Mugham that is unchangeable and only transfer from a body to another body that so called becoming Don to Don. Mugham is also like spirit is the fixed container of meanings that speaks though instrument and unchangeable and here it is instrument or Tanbour that can change just like the body.

\subsection{Number Seven and Mugham Relations}

The basis of fretting Tanbour is thirteen frets and fourteen sounds and moreover to these thirteen sounds open hand sound makes fourteenth sound. This set of sounds is allegory of two sevens (Haft) that have semantic compliance with "Haft-Tan" (First Grade fellowships of Sultan Isaac) and "Haftvaan" (God after creating Seven people from his essence, created Haftvaneh from his light and brilliance). Implementing names of Ahl-e-haqq saints with frets in Tanbour, the following results are drawn. (Table 1)

Table 1.Matching Holy Names of Yarsan with Tanbour Fretting

\begin{tabular}{|c|c|}
\hline Soltan Eshagh - open hand & Pir Benyamin ( Haftan) \\
\hline 1-th fret & Davood \\
\hline 2-th fret & Pir Musa \\
\hline 3-th fret & Ramzbar \\
\hline 4-th fret & Shahe Ebrahimi \\
\hline 5-th fret & Yadegar \\
\hline 6-th fret & Seyed Mohamad (Haftovan) \\
\hline 7-th fret & Seyed Amrolah \\
\hline 8-th fret & Seyed Serolah \\
\hline 9-th fret & Seyed Shahabedin \\
\hline 10-th fret & Seyed Jalal \\
\hline 11-th fret & Seyed Bab Veisi \\
\hline 12-th fret & \\
\hline &
\end{tabular}

Table 1 is described as follows:

- Absolute melody of string and "Akhvaan" is mainly constant voice and belong to God or the "Sultan Isaac"

- Absolute melody of string is melodies belong to eternal master "Gabriel" or "Benjamin", first and second frets are "David" and "Master Moses" and third fret which is fourth sound is belong to "Mustafa"

-"Khatoun-Ramz-Baar" which is allegory of fertility in relation with fifth sound and in fact, is fourth "Dastaan"

-Other remained names are "Haf-Tan" and "Haftvan" 


\subsection{Description and Analysis (Tahir Yarwaisi Version)}

Out of seventy two Mughams, around sixty six Mugham remained. Master Tahir Yarwaisi narration is chosen for analysis regarding to originality of performing Mughams and vocals in Goran region.

In this study, three Mughams of Haqqani Mughams which are very sacred for Yarsan are described as follows:

\section{.Aali-Gorzeh-Vish" Mugham}

The story of this Mugham dated back to the time of Sultan Isaac. According to narrations, huge number of people of Iraq and Baghdad came to Sultan Isaac complaining about oppression of Sultan Salim, Ruler of Baghdad. Sultan Isaac commissioned "Aali Qalandar" to give advice to Sultan Salim and invite him to justice, but Sultan Salim order to behead "Aali Qalandar" accused of his arrogance. "Aali Qalandar" took his head in his hand move toward "Pardivar". In Kalaam, mace is a metaphor of Aali Qalandar's head. (Fig.1)

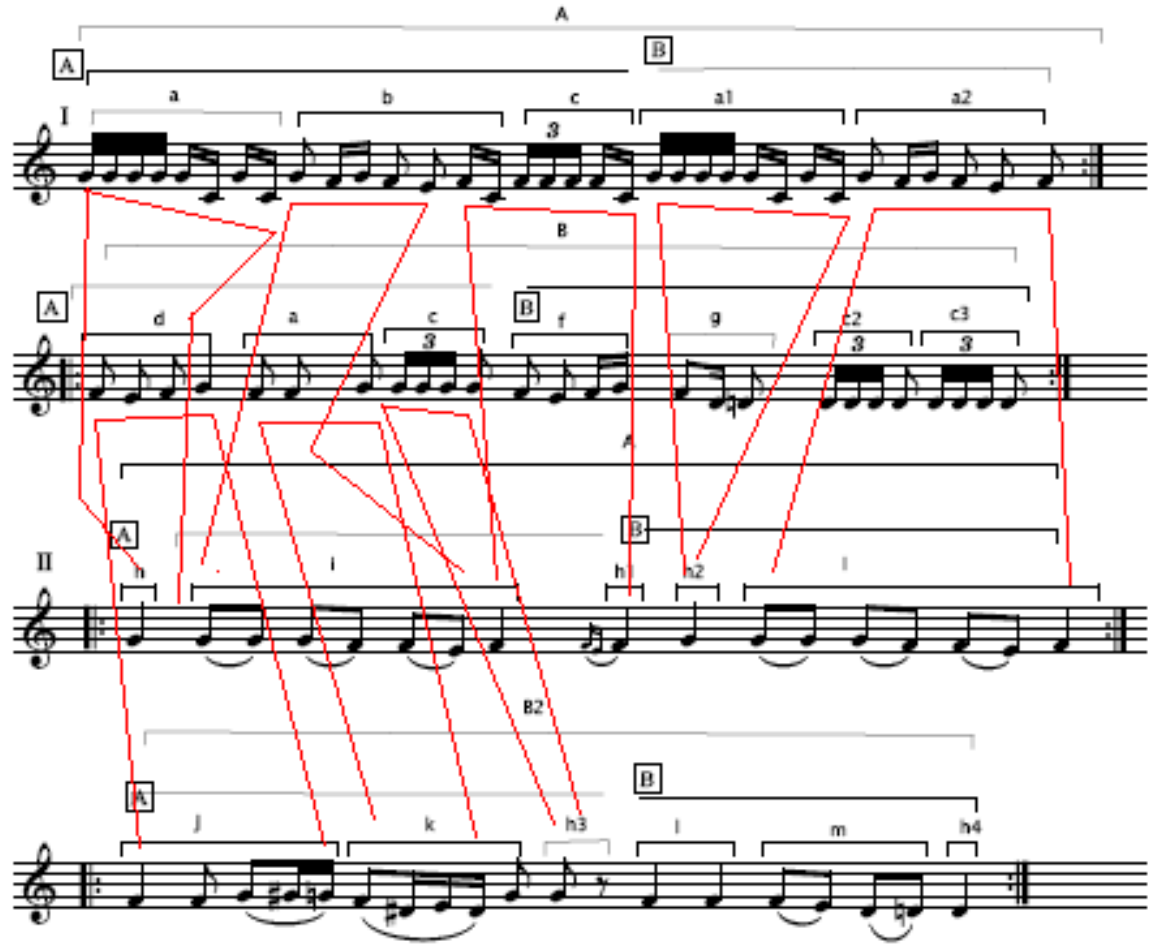

Fig.1 Ali-Gorzeh-Vish

"Aali-Gorzeh-Vish"s and "Daseh-veh" (mace here means, inner mace or Aali-Qalandar's head that serves Haqq and campaigns unjustly).

\section{iali gorze wish ha wa dasa wa}

AAli-Qalandar have mace (Gorz: metaphor of his head) in his hand

\section{miyahu va day ferei kasa wa}

and will bring justice for many people

This Mugham has two sections of: I- Instrumental and II- Instrumental-Vocal, each section has two parts of $A, B, A^{\prime}$ and $B^{\prime}$. Each section has two periods of $A$ and $B$ and each period itself is a compound of some figures a, b, c, d, etc. 


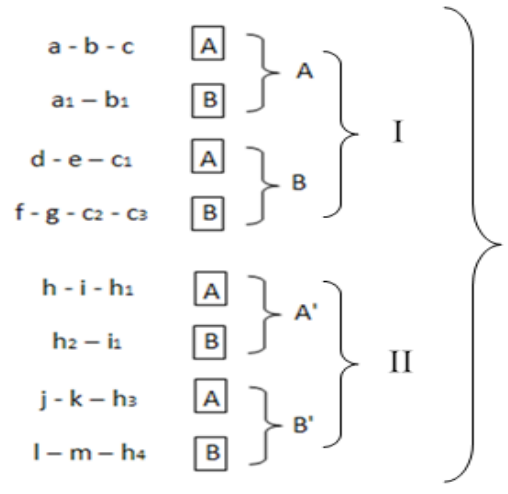

Fig.2 Structural analysis of AAli-Gorze-Wish Mugham

Instrumental and vocal-instrumental section follows a general form. Reason of this matter moreover to originality of vocal and continuity of sounds is relation of two "Naa-dooni" or reincarnations which its translation mentioned in musical Mughams of Ahl-e-Haqq. In this form that A and B have always repeated but in each reappearance get e fresh perspective.

In Ahl-e-Haqq rituals Kalaam and Tanbour are placed along each other i.e. Tanbour and its music is mirrorcontinuity of Kalaam. This is the same relation that present between God and man among Ahl-e-Haqq. In Yarsan philosophy man and God are beside each other and man during his journey to perfection is always a reflection of divine mirror. Man though "Don-a-Don" and surfing in various garments is walking toward perfection and God. Therefore, Kalaam is a metaphor of man's spirit (divine essence) that will live in different garments and itself is unchangeable and Tanbour is that man garment that changed and become "Don to Don".

\section{Haqq-Haqq and Hu-Hu-Ey-Aghaye-Jaafam Mughams}

This Kalaam is composed in the time of proposing "Khatoun-Dayraak" mother of Sultan Isaac for chief of Uraman tribe which is father of "Khatoun-Dayraak". Chief of Uraman had "Mazharyat" honor but he did not know himself. Non-exorbitant companion here is metaphor of Chief of Uraman's humility.

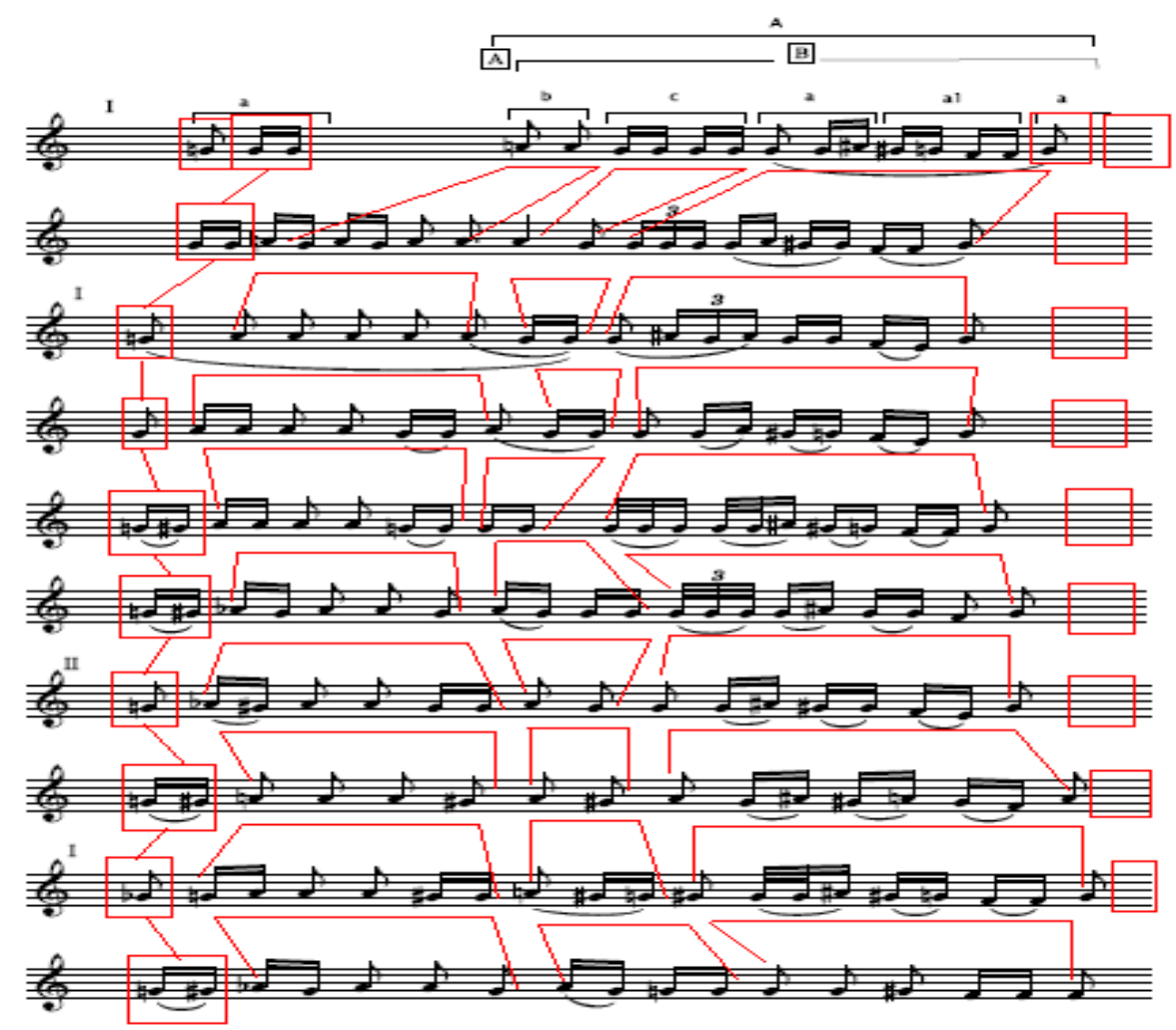

Fig.3 Haqq-Haqq Hu-Hu-Ey-Aghaye-Jaafam 


\section{Qanray sar taa faan yar be-gazafam}

Shouting Haqq-Haqq and Hu-Hu, devote myself to you Mr. "Jaaf"

That such as an ebullient fountain, my companion, I am not high-flown

-Mr. Jaaf pointed Sultan Isaac grandfather. He was the chief of "Jard" tribe. "Jard" tribe sometimes called "Jaaf".

-"My Non-exorbitant companion" means "My true companion" (meaning humility and modesty while being in powerful and having dignity)

-when a Dhikr begins with words such as Haqq-Haqq or Hu-Hu, it means your name is equal to divine Dhikrs.

-Haqq and Hu are two sacred names in texts of Ahl-e-Haqq; in this Mugham repeating Haqq and Hu is for creating Dhikr mood, emphasizing on importance of concept and creating loop. Repeating sacred names considered to be Dhikr; Dhikr that has movement and directional but changing rhythm is utilized to guide participants. Musical alteration of Dhikr in Ahl-e-Haqq Mughams is done through presence of rhythm and repeated musical forms. (Fig. 4) Dalahu is one of the sacred lands of Ahl-e-Haqq. In Dalahu many of the companions have appeared and it is also a place for meetings.

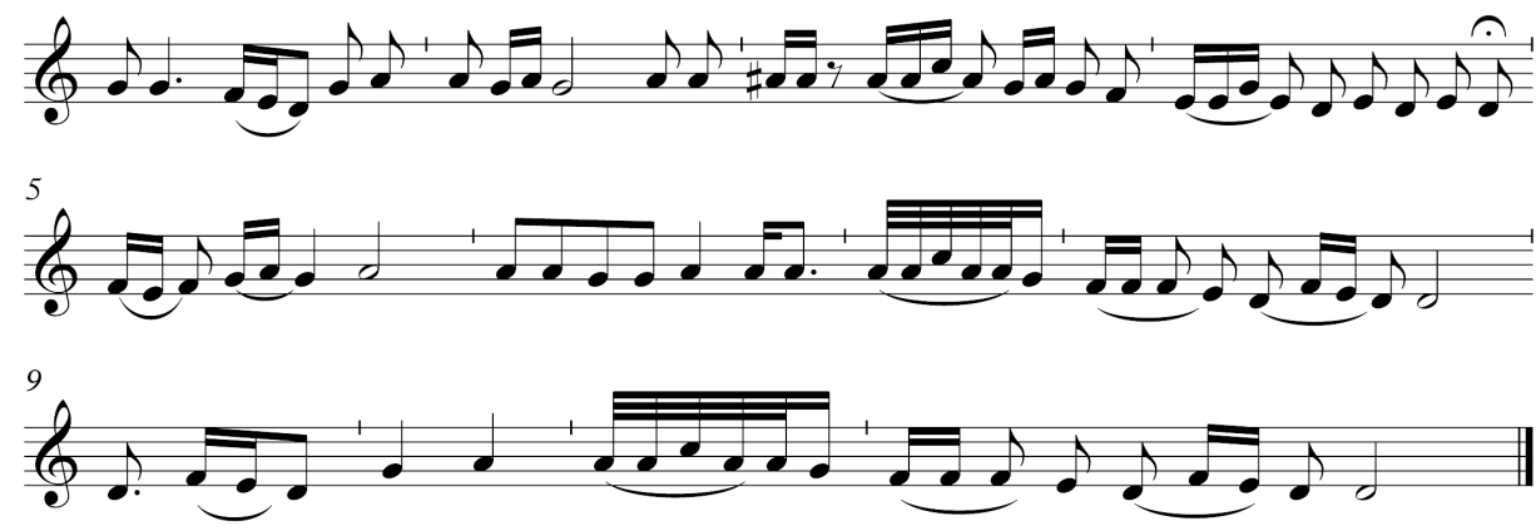

Fig.4 Rezhyan Dalahu

\section{Ey Dida - o-Kani}

Hey, my eyesight

\section{Rezhyan-Dalahu}

\section{Adorned Dalahu}

\section{Vastanesh Wana Shahu Balamu}

\section{Decorated Dalahu and then Shahu and Balamu}

Dalahu is considered as an earthly Paradise that has been decorated by divine essence and this divine essence is emerged in "Baba-Yadegaar" that manifested in this form in Dalahu. This Mugham shows various hierarchical stages in Yarsanism though steps movements in music.

Noticing steps movements of melodies in "Rezhyan-Dalahu" Mugham proved that circle of melodies in Ahl-eHaqq Mughams is affected by deep meaning of words and Kalaams, in "Dalahu" lands levels get meaning and its nature is a version of a sacred place in ideal divine thoughts and consequently Ahl-e-Haqq. In vocal styling of "Rezhyan-Dalahu" Mughams showing of stages clearly can be heard. Sentences move toward bass sounds step by step.(see figure 5)

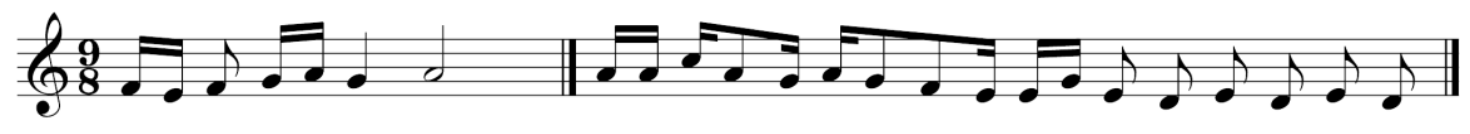

Fig. 5 Interpretation of Yarsan hierarchy as steps figures in their music 
Allegorical compliance between motifs with "Dalahu" steps environment which is because of its mountains might be true, and as it is mentioned in Ahl-e-Haqq Sufism, there are many dignities for different people; therefore, it can be concluded that in Mugham backend and under the influence of "Dalahu, a poetic narration of hierarchy that have similarities in nature and human emerged.

\section{LANGUAGE, MUSIC, AND MYSTICISM}

Since music is a means of expressing and transmitting culture, civilization, language and history of nations and tribes, maintaining and developing traditional music of each nation and tribe caused preventing their language, tradition and culture elimination and as a result considered as one of the retention factors in preserving cultural identity of that tribe.

Music in fact, is the language of dreams, expectations and emotions of human, and every nation according to its cultural characteristics, has its own special music. Tanbour music is also have a narrative mood and with its sound narrates history of its nation. Tanbour's rich music played and plays an effective role in distributing original Yarsan culture and strengthening their national identity, transmitting and popularizing original but less-used or even forgotten Kurdish words.

Best samples of Yarsan texts are "Kalaam", "Khazaaneh", or "Saranjaam" that in fact, are a set of religious treatises of Ahl-e-Haqq which have been written by Sultan Isaac and his fellowship in eighth century AH. "Saranjaam" have six section or part named: "Bargah-Bargah", "Haftvaneh Times", "Kilim and Koul", "ChehelTan Times", "Saints Times", and "micro-Saranjaam" that a great portion of divine Kalaams of Ahl-e-Haqq which sing and play in "Jam-Khaaneh" are parts of this book. Verses of this book which singed since centuries ago by Kalaam singers and performed by Tanbour masters in Jam-Khaaneh ceremonies along with instrument sound; separation of these two in ceremonies is not possible. And in this way, from crossing of music, that influence spirit of man directly, spiritual Kalaams of this cult is also stamped on human's spirit eternally and meanwhile ancient language of Yarsan is also transferred by words of month and from a generation to the future generation. In other words, music passes language and tradition that maintained for centuries to the future; as it quoted in one of the Kalaams of Ahl-e-Haqq:

\section{Yar didakani, Benyamin saza, Pir Mosi sima, Davood avaza}

Means: hey, companion of my eye and soul, Benjamin Holiness is sculpture himself,

\section{Master Moses is string of this instrument and}

\section{David is a vocal that comes from that side}

This Kalaam clearly shows the bond of music with mysticism of this cult and on the other side bonds of this two with ancient language of Yarsan because, words of this Kalaam which is composed in eighth century $\mathrm{AH}$, utilized with the same form and meaning todays.

\section{CONCLUSION}

Findings of this research show that rich music of Yarsan which is full of ancient melodies, is one of the factors in preserving, popularizing and transferring generation to next generation of Yarsanism rituals. This music while composing and performing ancient Kalaams of this ritual though instrument and vocal, itself is a musical interpretation of deep mystical concepts. Because, as believed by right masters of Yarsan music, whatever is truth will reflect itself by any form and mirror.

Also, finding of this study stated that, Tanbour music because of its holiness and its unique position among Yarsan, preserved language, literature and mysticism of this cult in itself and passes this treasure to good trustees of Yarsan from a generation to the next. Also, regarding this point that in terms of language, ancient texts of Yarsanism that remained from eighth century AH (Sultan Isaac era) is still popular among Yarsan and for understanding it, they do not need much translation; it can be concluded that, in the fled of music too changes are in a form that, despite whatever of ancient music which has been lost and had a close tie to spirituality, still can go further. With a minor difference that, because music was not a written and passes generation to generation practically, it had undoubtedly more changes than language.

In this way, and to get closer to the truth of ancient music of nations and also finding equivalent mystical concepts in religious music of ancient lands it is suggested by researchers that mysticism and mystical music of various regions together titled "Mysticism and Mystical Music" or "Ritual and Ritual Music" can be the future study subjects. 


\section{ACKNOWLEDGEMENT}

The authors would like to thank Sharyari, Seyed Arash; Yarwaysi, Sayed Taher; Moradi, Ali Akbar as great masters of Tanbour in western side of Iran for give a chance to the researchers to do interviews with them.

\section{REFERENCE LIST}

Aalinejad, Sayed Khalil. (1997), Tabor from ancient times till now, Knowledge and technique Press.

Ardalan, Hamidreza. (2007), Historical and mythical interpretation of rituals of devotees, the Kurd Sufis and Dervishes of Iran, PHD Thesis (Arts Studies Field), Art University Of Tehran.

Darvishi, Mohammad Reza. (2001), Haft Ourang (A review of local and traditional music of Iran), Houzeh Honari Press.

Darvishi. Mohammad Reza. (2001). Encyclopedia of Iranian instruments (1) Volume I - String, Plectrum and a bowed Instruments of Iran, Mahour Press.

During, Jean. (1989), Musique et Mystique dans les traditions de L'Iran. Institut Francais de recherché en Iran. Paris-Tehran.

Elahi, NoorAli. (1994), Burhan-al-Haqq, Jeyhoun Press.

Kaki, Heydar. (2009), Understanding Tanbour, Navid Shiraz Press.

Khodabandeh, Abdullah. (2003), Understanding Ahl-e-Haqq Sect, Amirkabir Press.

Minorsky, V. (1921), Secte des Ahle-Haqq. Ernest Lerox, Paris.

Mokri, Mohammad. (1966), Nur Ali-shah Elahi- Lesoterism Kurde. Edition Albin Michel, Paris.

Sedigh, Safizade. (1996), Final Letter (Khazaneh Kalaam, The most important Yarsanism old books), Hirmand Press.

Souri, Mashallah. (1965), Ritual hymns of Yarsanism, Amirkabir Press. 